\title{
Pengaruh Ekonomi Orangtua Terhadap Motivasi Belajar Matematika Siswa Kelas VIII SMP Negeri 9 Padangsidimpuan
}

\author{
Oleh: \\ Nirma Wahyuni \\ Suparni
}

\begin{abstract}
Many of the effects of the economy are family resilience, family resilience is realized because the functioning of the family in meeting all physical and psychological needs, namely economic needs, education, hereditary instincts, instincts of compassion, protection and social affection. If the family's resilience has begun to be fragile it will have a bad influence on students' learning motivation if the child's learning motivation is no longer there and how to carry out education well. Therefore, as a component of education for both parents, the teacher must know the mentality of the child in order to be able to carry out education as well as possible.

This study aims to determine the economics of parents in Padangsidimpuan 9th Middle School. To find out the motivation to learn Grade VIII Mathematics of SMP Negeri 9 Padangsidimpuan.

This study uses a correlational method with a quantitative type, which provides an overview and simultaneously sees the influence of the two variables by calculating the mean, median, mode, variance and standard deviation. To provide an interpretation of the distribution of data obtained from the population are all class VIII SMP N 9 Padangsidimpuan about 227 students. The sampling technique carried out by researchers with cluster random sampling samples consisted of 45 VIIII and VIII2 classes. Then the instruments used as data collection is using a questionnaire and managed using a correlational method then analyzed using product moment obtained by rxy $=0.172$ compared with a significant level of $5 \%=0.294$ including the non-significant category with a coefficient of determination $(\mathrm{kp})=2.96 \%$ means that the parent economy contributes not significant to students' motivation to learn Mathematics. While the manager of data analysis is done by using linear regression which shows fcount $<$ ftabel $=1.307<4.075$ Significant level $a=35.259$ and $b=0.158$ and $n$ $=45$ with one-sided test $\mathrm{dk}=\mathrm{n}-2=43$, so that ftabel $=4.075$. Seeing this condition, the hypothesis test rejects $\mathrm{H} 0$ and the recipient. Ha This study concludes that there is no significant influence between parents' economics on
\end{abstract}


the motivation to learn Mathematics in Class VIII SMP Negeri 9 Padangsidimpuan.

\begin{abstract}
ABSTRAK
Banyak dampak yang diakibatkan dari ekonomi salah satunya adalah ketahanan keluarga, ketahanan keluarga terwujud karena berjalannya fungsi keluarga dalam memenuhi semua kebutuhan fisik dan juga psikisnya yakni kebutuhan ekonomi, pendidikan, naluri berketurunan, naluri bergama, kasih sayang perlindungan dan sosial. Jika ketahanan keluarga sudah mulai rapuh akan menyebabkan pengaruh yang buruk terhadap motivasi belajar anak didik jika motivasi belajar anak tidak ada lagi lalu bagaimana untuk melaksanakan pendidikan dengan baik. Oleh sebab itu, sebagai komponen pendidikan baik orangtua, guru harus mengetahui kejiwaan anak agar dapat melaksanakan pendidikan dengan sebaik mungkin.

Penelitian ini betujuan Untuk mengetahui ekonomi orangtua siswa di SMP Negeri 9 Padangsidimpuan.Untuk mengetahui motivasi belajar Matematikasiswa Kelas VIII SMP Negeri 9 Padangsidimpuan.Untuk mengetahui apakah ada pengaruh yang signifikan antara tingkat ekonomi orangtua terhadap motivasi belajar Matematika siswa Kelas VIII SMP Negeri 9 Padangsidimpuan.

Penelitian ini menggunakan metode korelasional dengan jenis kuantitatif, yaitu memberikan gambaran dan sekaligus melihat pengaruh antara kedua variabel dengan menghitung mean, median, modus, variansi dan simpangan baku. Untuk memberikan penafsiran sebaran data yang diperoleh terhadap populasi adalah seluruh kelas VIII SMP N 9 Padangsidimpuan sebanyak 227 siswa, Teknik pengambilan sampel yang dilakukan oleh peneliti dengan cluster random sampling sampelnya adalah terdiri dari kelas $\mathrm{VIII}_{1}$ dan $\mathrm{VIII}_{2}$ sebanyak 45 orang Kemudian instrumen yang digunakan sebagai pengumpulan data adalah dengan menggunakan angket dan dikelola dengan menggunakan metode korelasional kemudian dianalisis dengan menggunakan product moment diperoleh $r_{x y}=0,172$ dibandingkan dengan taraf signifikan $5 \%=0,294$ termasuk kategori yang tidak signifikan dengan koefisien determinasi $(\mathrm{kp})=$ 2,96\% artinya ekonomi orangtua memberikan konstribusi yang tidak signifikan terhadap motivasi belajar Matematika siswa. Sedangkan pengelola analisis data dilakuan dengan menggunakan regresi linier yang menunjukkan $\mathrm{f}_{\text {hitung }}<\mathrm{f}_{\text {tabel }}=$ $1,307<4,075$ Taraf signifikan $\mathrm{a}=35,259$ dan $\mathrm{b}=0,158$ dan $\mathrm{n}=45$ dengan uji satu fihak $d k=n-2=43$, sehingga diperoleh $f_{\text {tabel }}=4,075$. Melihat kondisi ini maka uji hipotesis penolakan $\mathrm{H}_{0}$ dan penerima $\mathrm{H}_{a}$ penelitian ini menyimpulakan bahwa tidak ada pengaruh yang signifikan antara ekonomi orangtua terhadap motivasi belajar Matematika siswaKelas VIII SMP N 9 Padangsidimpuan.
\end{abstract}

\title{
Kata kunci : Ekonomi Orangtua, Motivasi Belajar Matematika Siswa
}




\section{A. Pendahuluan}

Indonesia merupakan negara yang kaya akan sumber daya alam (SDA). Dilihat dari letaknya, Indonesia terletak pada sisi yang sangat strategis. Sumber daya alam yang melimpah ruah seharusnya ini dijadikan sebagai modal untuk menjadi negara yang maju dan sejahtera. Namun tetap saja Indonesia belum juga dapat sepenuhnya menjadi negara yang mandiri baik dibidang ekonomi, politik, maupun pertahanan dan keamanan.

Perekonomian indonesia sejak krisis ekonomi pada pertengahan 1997 ketenaga kerjaan indonesia ikut memburuk, sejak itu pertumbuhan ekonomi juga tidak pernah mencapai 7-8 persen. Padahal pengangguran erat kaitannya dengan pertumbuhan ekonomi. ${ }^{1}$ Dari banyaknya masyarakat yang penganguran sehingga menimbulkan kemiskinan. Sementara harga bahan pangan semakin melonjat. Bahkan dipemberitaan media, banyak keluarga yang hidup dalam kondisi yang memperihatinkan. Dan bisa dipastikan korban dari kerasnya hidup adalah genarasi penerus bangsa, yaitu anak-anak bangsa.

Banyak dampak yang diakibatkan dari tingkat ekonomi salah satunya adalah ketahanan keluarga, ketahanan keluarga terwujud karena berjalannya fungsi keluarga dalam memenuhi semua kebutuhan fisik dan juga psikisnya yakni kebutuhan ekonomi, pendidikan, naluri berketurunan, naluri bergama, kasih sayang perlindungan dan sosial. Dalam 5 tahun terakhir 2010-2015 angka perceraian meningkat $59-80 \%$ mayoritas adalah gugat cerai karena faktor ekonomi, KDRT, perselingkuhan dan lain-lain, ini akan berdampak negatif pada motivasi anak dalam belajar sehingga anak acuh tak acuh dalam belajar, dan anak berpikir untuk mencari pelarian untuk menenangkan diri, inilah yang menyebabkan banyak anak-anak terjerumus terhadap perilaku penyimpangan, mulai dari hal-hal yang kecil hingga berakibat patal untuk anak, seperti malas belajar, bolos sekolah hingga berhenti sekolah, bahkan menggunakan obat-obat terlarang, pergaulan bebas bahkan berani melecehkan orang-orang sekitarnya yang lebih miris adalah pembunuhan. Perilaku seperti ini sudah banyak terjadi dimasyarakat.

ekonomi orangtua juga bisa berdampak positif terhadap motivasi belajar anak. Untuk bisa mencapai masa depan yang lebih cerah, sehingga menimbulkan motivasi yang begitu besar dari anak.

Bangsa Indonesia membutuhkan menusia-manusia yang mempunyai kompetensi dan komitmen untuk bersama-sama membangun bangsa Indonesia kedepannya. Salah satu cara untuk menumbuhkan kompetensi dan komitmen adalah dengan melalui pendidikan. Rendahnya kualitas penduduk merupakan salah satu penyebab kemiskinan disuatu negara. Ini disebabkan karena rendahnya pendidikan dan pengetahuan, untuk adanya pengembangan ekonomi jelas dibutuhkan tenaga kerja yang mempunyai skill dan kompetensi. Lemahnya ekonomi orangtua sebagian besar disebabkan rendahnya pendidikan orangtua, observasi yang dilakukan dikampung peneliti

${ }^{1}$ Diana Apriliyanti, Terjadinya Kemiskinan, Pengangguran dan Kesenjangan Ekonomi(http:dianaapriliyanti blogspot.co.id, 2013, diakses 18 November 2015 pukul 13.20 wib). 
sendiri. Melihat sebagian besar orangtua yang ekonominya rendah termasuk tingkat pendidikannya rendah kebanyakan dari mereka lulusan SMP dan SD. Sedangkan orangtua yang lulusan SMA sampai Perguruan tinggi, lebih berkembang dan maju.

Sangat jelas perbedaannya orangtua yang pendidikannya tinggi dengan pendidikannya rendah, mulai dari cara mereka mendidik anaknya, mengatur keluarganya hingga megolah lahan mereka. Orangtua yang pendidikannya tinggi lebih memperhatikan pendidikan anaknya, dan cara mereka mendidik anaknya lebih bijaksana, begitu juga dengan megolah lahan orangtua yang pendidikannya tinggi lebih mengetahui pupuk apa yang cocok untuk pertaniannya, bagaimana seharusnya lahan itu dibuat agar menghasilkan panen yang lebih bagus.

Sangat berbeda dengan orangtua yang pendidikannya lemah pemikirannya sangat monoton atau tidak berkembang, orangtua menyekolahkan anaknya, hanya sebatas sekolah saja tidak memperhatikan bagaimana agar anaknya bisa sekolah hingga perguruan tinggi. Dalam mengolah pertanian pun, dengan menggunakan cara-cara yang lama tidak berkembang cara pengolahannya, sehingga hasil panennya tetap seperti itu tidak bertambah bahkan berkurang. Sehingga pemenuhan kebutuhan seharihari tidak mencukupi yang akhirnya dana Boss yang dikeluarkan pemerintah bukan lagi dipergunakan untuk biaya anak sekolah namun untuk memenuhi kebutuhan sehari-hari. Oleh karena itu pendidikan merupakan modal utama untuk merubah hidup lebih maju.

Pendidikan dapat didefenisikan sebagai usaha yang sadar, teratur, dan sistematis di dalam memberikan bimbingan atau bantuan kepada orang lain (anak) yang sedang berproses menuju kedewasaan. ${ }^{2}$

Pendidikan merupakan proses budaya untuk meningkatkan harkat dan martabat manusia, karena itu pendidikan merupakan tanggung jawab bersama antar keluarga masyarakat dan pemerintah. Pendidikan perlu disesuaikan dengan perkembangan tuntunan dan pembangunan yang memerlukan jenis keterampilan dan keahlian disegala bidang serta ditingkatakan mutunya sesuai dengan kemajuan ilmu dan perkembangan teknologi.

Berbagai usaha dilakuan untuk mengatasi masalah mutu pendidikan usaha yang dilakukan untuk mengatasi masalah kualitas pendidikan yaitu pembaharuan kurikulum dan proses belajar mengajar, meningkatkan kualitas guru, pangadaan buku pelajaran dan sarana belajar lainnya. Penyempurnaan sistem penilaian, perhatian organisasi dan manajemen pendidikan serta usahausaha lain yang berkaitan dengan meningkatkan kualitas pendidikan. Meskipun berbagai usaha telah dilakukan untuk meningkatkan mutu pendidikan namun lulusan sekolah masih dipertanyakan orang lain. Selain itu penyebab tersebut juga berasal dari pihak orangtua kepada anaknya yang tidak terarah sebagaimana mestinya. Jumlah anggota keluarga yang banyak, dan ekonomi yang tidak mencukupi sehingga menyebabkan perhatian, kasih

${ }^{2}$ Suharko Hari S, Pengantar Sosiologi(Klaten Utara : Intan Pariwara, 1996), hlm.95 
sanyang dan juga kebutuhan anak tidak dapat terpenuhi oleh orangtua dan juga termasuk pendidikan orangtua yang rendah yang turut mempengaruhi motivasi belajar anak.

Dalam proses pembalajaran faktor motivasi anak dalam belajar menjadi tantangan tersendiri yang harus dihadapi dan diselesaikan oleh seorang guru. Selain bertugas untuk menyampaikan materi pelajaran, guru juga memiliki peran dikelas salah satunya untuk membangkitkan motivasi belajar siswa. Motivasi belajar merupakan salah satu determinan penting dalam belajar, para ahli sukar mendefenisikannya, akan tetapi motivasi berhubungan dengan, arah perilaku, kekuatan respon yaitu usaha setelah belajar siswa memilih mengikuti tindakan tertentu dan ketahanan perilaku, atau beberapa lama seseorang itu terus menerus berperilaku menurut cara tertentu. ${ }^{3}$

Unsur-unsur yang mempengaruhi motivasi belajar antara lain; citacita atau aspirasi siswa, kemampuan siswa, kondisi lingkungan siswa, unsurunsur dinamis dalam belajar dan pembelajaran, adanya upaya guru dalam megajarkan siswa. Salah satu unsur yang mempengaruhi motivasi belajar di atas yaitu kondisi lingkungan siswa. Kondisi lingkungan siswa ini termasuk kondisi ekonomi orangtua. Kondisi orangtua sangat berpengaruh terhadap motivasi belajar siswa.

SMP Negeri 9 merupakan sekolah yang akan peneliti teliti karena sekolah itu merupakan alumni peneliti sehingga peneliti tertarik untuk melihat apakah di sekolah tersebut ada pengaruh dari ekonomi ini terhadap motivasi siswa disana.

Dari latar belakang yang dipaparkan sehingga penulis merasa tertarik untuk mengadakan kajian lebih mendalam yang berjudul, Pengaruh Ekonomi Orangtua Terhadap Motivasi Belajar Matematika Siswa Kelas VIII SMP Negeri 9 Padangsidimpuan.

\section{B. Metodologi Penelitian}

\section{Tempat dan Waktu Penelitian}

Penelitian ini dilaksankan di SMP Negri 9 Padangsidimpuan yang beralamat di JL.Merdeka Km.4,5 Hutaimbaru, Kecamatan Padangsidimpuan Hutaimbaru. Penelitian ini dilaksanakan tepatnya pada Semester Ganjil tahun ajaran 2016-2017 yaitu pada bulan 16 Mei 2016 sampai dengan 25 Desember 2016.

\section{Jenis Penelitian}

Penelitian ini merupakan penelitian kuantitatif dengan menggunakan metode korelasional.

${ }^{3}$ Martinis Yamin, Profesionalisasi Guru dan Implementasi Ktsp (Jakatra : Putra Grafika, 2009), hlm.157. 


\section{Populasi dan Sampel}

Populasi penelitian ini adalah siswa SMP Negeri 9 Padangsidimpuan. Sementara sampel yang diambil adalah kelas $\mathrm{VIII}_{1}$ dan $\mathrm{VIII}_{2}$ dari jumlah populasi siswa kelas VIII sehingga diperoleh sampelnya sebayak 45 orang.

\section{Instrumen Pengumpulan Data}

Teknik pengumpulan data adalah dengan menggunakan angket.

\section{Uji Validitas dan Reliabilitas Instrumen}

Sebelum angket digunakan sebagai alat pengumpulan data terlebih dahulu diuji cobakan terhadap 35 orang sampel yang diambil secara acak (random sampling).

1) Validitas Angket

Mencari validitas angket yaitu menggunakan rumus korelasi product moment sebagai berikut :

$$
r_{x y}=\frac{n \cdot\left(\sum X Y\right)-\left(\sum X\right)\left(\sum Y\right)}{\sqrt{\left\{n \cdot \sum X^{2}-(X)^{2}\right\}} \cdot\left\{n \cdot \sum Y^{2}-(Y)^{2}\right.}
$$

Keterangan :

$r_{x y}=$ koefisien korelasi

$N$ = banyaknya subjek pemilik nilai

$X \quad=$ nilai variabel 1

$Y=$ nilai variabel $2 .{ }^{4}$

b) Reabilitas Angket

Reabilitas instrumen yang bukan tes perlu dicari, untuk instumen yang dapat diberi skor dan skornya bukan 1, uji coba dapat dilakukan dengan teknik satu kali saja kemudian hasilnya dianalisis dengan rumus alpha rumus berikut :

$$
r_{11}=\left[\frac{k}{k-1}\right]\left[1-\frac{\sum \sigma_{b}^{2}}{\sigma_{t}^{2}}\right.
$$

Keterangan :

$r_{11}=$ reabilitas intrumen

$\mathrm{k} \quad=$ banyaknya butir pertanyaan atau banyaknya soal

$\sum \sigma_{b}^{2}=$ jumlah varians butir

$\sigma_{t}^{2}=$ varians total.

Rumus varians total :

$$
v_{1}=\frac{\sum x^{2}-\frac{\left(\sum x\right)^{2}}{N}}{N}
$$

Kemudian nilai dari $r_{\text {hiting }}$ tersebut dibandingan dengan $r_{\text {tabel }}$ apabila $r_{h}$ $>r_{t}$ maka angket tersebut reabel dan begitu juga sebaliknya

${ }^{4}$ Suharsimi Arikunto, Managemen Penelitian (Jakarta : Rineka Cipta, 2009), hlm. 425-426. 


\section{Analisis Data}

Dalam melakukan analisis terhadap data yang diperoleh dilakukan dengan cara:

1. Analisis korelasional

Teknik yang digunakan adalah product moment correlation

$$
r_{x y}=\frac{\mathrm{n} \cdot\left(\sum \mathrm{XY}\right)-\left(\sum \mathrm{X}\right)\left(\sum \mathrm{Y}\right)}{\sqrt{\left\{n \cdot \sum X^{2}-(X)^{2}\right\} \cdot\left\{n \cdot \sum Y^{2}-(Y)^{2}\right.}}
$$

Korelasi product moment dilambangkan dengan $\mathrm{r}$ dengan ketentuan nilai $r$ berada diantara $-1<\mathrm{r}<1$. Apabila nilai $\mathrm{r}=-1$ artinya korelasinya negatif sempurna, untuk $r=0$ artinya tidak ada korelasi dan untuk $\mathrm{r}=1$ berarti koefisiennya Positif sempurna.

Selanjutnya untuk menyatakan besar kecilnya konstribusi (sumbangan) variabel $\mathrm{X}$ terhadap $\mathrm{Y}$ dapat ditentukan dengan rumus koefisien determinasi sebagai berikut:

$\mathrm{KD}=\mathrm{r}^{2} \mathrm{x} 100 \%$

Keterangan: $\mathrm{KD}=$ Nilai koefisien determinasi

$\mathrm{r} \quad=$ Nilai koefisien korelasi

2. Analisis regresi linier

Dalam melakukan analisis terhadap data yang diperoleh untuk mengetahui pengaruh $\mathrm{X}$ terhadap $\mathrm{Y}$, dilakukan analisis regresi linier sederhana. Perhitungan persamaan regresi $\mathrm{X}$ dan $\mathrm{Y}$ dengan mencari persamaan regresi sebagai berikut :

$$
\dot{Y}=a+\mathrm{Bx}
$$

Keterangan :

Ý = subjek variabal terikat yang diproyeksikan

$\mathrm{X}=$ variabel bebas yang mempunyai nilai tertentu untuk diprediksikan

$\mathrm{a}=$ nilai konstanta harga $\mathrm{Y}$ jika $\mathrm{X}=0$

$\mathrm{b}=$ nilai arah sebagai penentu ramalan yang menunjukkan nilai peningkat (+) atau nilai penurunan (-) variabel Y

Langkah-langkah menjawab uji regresi sederhana :

a. Buatlah $\mathrm{H}_{\mathrm{a}}$ dan $\mathrm{H}_{0}$ dalam bentuk kalimat

b. Buatlah $\mathrm{H}_{\mathrm{a}}$ dan $\mathrm{H}_{0}$ dalam bentuk statistik

c. Buatlah tabel penolong menghitung angka ststistik

d. Masukkan angka-angka statistik dari tabel penolong dengan menggunakan rumus :

$b=\frac{n \sum X Y-\sum X \cdot \sum Y}{N \cdot \sum X^{2}-\left(\sum X\right)^{2}} \quad a=\frac{\sum Y-b \cdot \sum X}{n}$

e. Hitung jumlah kuadrat regresi $\left[\mathrm{JK}_{\mathrm{Reg}(\mathrm{a})}\right]$ dengan rumus :

$\mathrm{JK}_{\mathrm{Reg}}=\frac{\sum Y^{2}}{n}$

f. Hitung jumlah kuadrat regresi $\left[\mathrm{JK}_{\mathrm{Reg}(\mathrm{b} \mid \mathrm{a})}\right]$ dengan rumus :

$\mathrm{JK}_{\operatorname{Rrg}(\mathrm{b} \mid \mathrm{a})}=b\left(\sum X Y-\frac{\sum X \cdot \Sigma Y}{n}\right)$

g. Hitung jmlah kuadrat residu [JK $\mathrm{JKes}_{\text {Res }}$ dengan rumus :

$\mathrm{JK}_{\text {Res }}=\sum Y^{2}-\mathrm{JK}_{\operatorname{Reg}(b \mid a)}-\mathrm{JK}_{\operatorname{Reg}(\mathrm{a})}$

h. Hitung rata-rata jumlah kuadrat regresi (a) $\left[\mathrm{JK}_{\mathrm{Reg}(\mathrm{a})}\right]$ dengan rumus:

$\mathrm{RJK}_{\operatorname{Reg}(\mathrm{a})}=\mathrm{JK}_{\mathrm{Reg}(\mathrm{a})}$ 
i. Hitung rata-rat jumlah kuadrat regresi (b|a) $\left[\mathrm{RJK}_{\mathrm{Reg(a)}}\right]$ dengan rumus $=\mathrm{RJK}_{\operatorname{Reg}(b \mid a)}=\mathrm{JK}_{\operatorname{Reg}(\mathrm{b} \mid \mathrm{a})}$

j. Hitung rata-rta jumlah kuadrat residu $\left[R J K_{\text {Res }}\right]$ dengan rumus :

$$
\mathrm{RJK}_{\mathrm{Res}}=\frac{\text { JKRes }}{n-2}
$$

k. Menguji signifikansi dengan rumus $\mathrm{F}_{\text {hitung }}$ :

$$
\mathrm{F}_{\text {hitung }}=\frac{R J K \operatorname{Reg}(b \mid a)}{R J K \operatorname{Res}}
$$

1. Menentukan aturan pengambilan keputusan atau kriteria uji signifikan: kaidah pengujian signifikansi :

Jika $F_{\text {hitung }} \geq \mathrm{F}_{\text {tabel }}$ maka $\mathrm{H}_{0}$ ditolak (signifikan)

Jika $F_{\text {hitung }} \leq \mathrm{F}_{\text {tabel }}$ maka $\mathrm{H}_{\mathrm{a}}$ ditolak (tidak signifikan)

m. Cari nilai Ftabel menggunakan Tabel $\mathrm{F}$ dengan rumus :

Taraf signifikansinya $\alpha=0,01$ atau $\alpha=0,05$

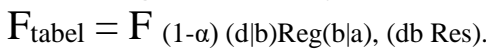

\section{Hasil Penelitian Dan Pembahasan}

\section{Hasil Uji Coba Instrumen Penelitian}

Uji coba instrumen dilakukan kepada 35 siswa kelas VIII SMP Negeri 9 Padangsidimpuan. Untuk mencari validitas (kesahihan) reliabilitas (ketetapan). Instrumen pengumpulan data yang digunakan pada penelitian ini adalah angket tingkat ekonomi (sebagai variabel $\mathrm{X}$ ) dan angket motivasi belajar (sebagai variabel Y) yang jumlah itemnya sebanayak 20 item.

Dari perhitungan yang dilakukan penulis, angket yang dilakukan uji coba validitas dan reliabilitas berjumlah 20 item. Ternyata setelah dilakukan uji coba diperolah angket ekonomi orangtua yang layak diuji coba sebanyak 16 item yaitu angket nomor, 1, 2, 4, 5, 6, 7, 8, 9, 12, 13, 14, 15,16, 17, 18, 19. Sedangkan yang tidak layak diujikan sebanyak 4 item yaitu angket nomor 3 , 10, 11, 20. Untuk lebih jelasnya dapat dilihat pada tabel berikut:

\begin{tabular}{|c|c|c|c|}
\hline Nomor Item & Nilai rhitung & Nilai $\mathbf{r}_{\text {tabel }}$ & Interprestasi \\
\hline 1 & 0,454 & \multirow{15}{*}{$\begin{array}{l}\text { Pada taraf } \\
\text { Signifikan } \\
5 \%(0,334)\end{array}$} & Valid \\
\hline 2 & $\mathbf{0 , 3 7}$ & & Valid \\
\hline 3 & $\mathbf{0 , 1 3 8}$ & & Tidak valid \\
\hline 4 & 0,523 & & Valid \\
\hline 5 & 0,766 & & Valid \\
\hline 6 & 0,882 & & Valid \\
\hline 7 & 0,615 & & Valid \\
\hline 8 & 0,704 & & Valid \\
\hline 9 & $\mathbf{0 , 7 3}$ & & Valid \\
\hline 10 & 0,172 & & Tidak valid \\
\hline 11 & $\mathbf{0 , 3}$ & & Tidak valid \\
\hline 12 & 0,408 & & Valid \\
\hline 13 & 0,765 & & Valid \\
\hline 14 & 0,836 & & Valid \\
\hline 15 & 0,862 & & Valid \\
\hline
\end{tabular}

Tabel 1. Hasil Uji Coba Angket Ekonomi Orangtua 


\begin{tabular}{|c|c|c|}
\hline 16 & $\mathbf{0 , 7 7 7}$ & Valid \\
\hline 17 & $\mathbf{0 , 8 2 3}$ & Valid \\
\hline 18 & 0,672 & Valid \\
\hline 19 & 0,757 & Valid \\
\hline 20 & 0,2 & Tidak valid \\
\hline
\end{tabular}

Dengan tingkat reabilitas $\mathbf{r}_{11}=\mathbf{0 , 8 2 4}$

Dan semua pertanyaan yang diujikan adalah reliabel (perhitungan dan nilai validitas dan reliabilitasnya dapat dilihat dilampiran 4 .

Sedangkan angket motivasi belajar yang bayak diujikan sebanyak 16 item yaitu angket nomor 1, 2, 3, 4, 6, 7, 8, 9, 10, 12, 14, 15, 17, 18, 19, 20. Sedangkan yang tidak layak diujikan sebanyak 4 item yaitu angket 5 , $11,13,16$. Untuk lebih jelasnya dapat dilihat pada tabel berikut.

Tabel 2.Hasil Uji Coba Angket Motivasi Belajar

\begin{tabular}{|c|c|c|c|}
\hline NO. Item & $\begin{array}{l}\text { Nilai } \\
\text { rhitung }\end{array}$ & Nilai r tabel & Interprestasi \\
\hline 1 & 0,801 & \multirow{20}{*}{$\begin{array}{c}\text { Pada taraf } \\
\text { Signifikan } \\
\mathbf{5 \%}(0,334)\end{array}$} & Valid \\
\hline 2 & 0,61 & & Valid \\
\hline 3 & 0,407 & & Valid \\
\hline 4 & 0,728 & & Valid \\
\hline 5 & 0,28 & & Tidak valid \\
\hline 6 & 0,428 & & Valid \\
\hline 7 & 0,746 & & Valid \\
\hline 8 & 0,755 & & Valid \\
\hline 9 & 0,654 & & Valid \\
\hline 10 & 0,692 & & Valid \\
\hline 11 & 0,285 & & Tidak vald \\
\hline 12 & 0,417 & & Valid \\
\hline 13 & 0,262 & & Tidak valid \\
\hline 14 & 0,486 & & Valid \\
\hline 15 & $\mathbf{0 , 3 9 1}$ & & Valid \\
\hline 16 & $\mathbf{0 , 0 7 9}$ & & Tidak valid \\
\hline 17 & 0,501 & & Valid \\
\hline 18 & 0,413 & & Valid \\
\hline 19 & 0,691 & & Valid \\
\hline 20 & 0,497 & & Valid \\
\hline
\end{tabular}

Dengan tingkat reabilitas $\mathbf{r}_{11}=\mathbf{0 , 8}$

\section{Deskripsi Data}

\section{a. Ekonomi Orangtua}

Dari hasil perhitungan jawaban responden terhadap pertanyaan yang diajukan dalam angket dengan menggunakan deskripsi skor-skor variabel ekonomi orangtua. Skor variabel yang diperoleh dari jawaban responden yang terdapat pada lampiran digambarkan pada tabel berikut : 
Tabel 3. Rangkuman Deskripsi Variabel Ekonomi Orangtua

\begin{tabular}{|c|c|c|}
\hline NO & NILAI & X \\
\hline 1 & Skor Tertinggi & 51 \\
\hline 2 & Skor Terendah & 24 \\
\hline 3 & Mean & 37,55 \\
\hline 4 & Median & 41,47 \\
\hline 5 & Modus & 41 \\
\hline 6 & Variansi & 10,066 \\
\hline 7 & Standar Deviasi & 3,173 \\
\hline
\end{tabular}

Dari tabel diatas skor tertinggi yang dicapai responden sebesar 51 sedangkan skor terendah 24 dan skor mean rata-rata sebesar 37,55 begitu juga tabel tersebut terlihat skor yang paling sering muncul (modus) adalah 41 dan nilai tengah (median) sebesar 41,47 sedagkan variansi sebesar 10,066 dan standar deviasi (simpangan baku) sebesar 3,173.

Dengan menentukan jumlah kelas yaitu 6 dan intervalnya 5 diperoleh sebesar skor ekonomi orangtua seperti yang ditunjukkan pada tabel berikut :

Tabel 4. Distribusi Frekuensi Ekonomi Orang Tua

\begin{tabular}{|c|c|c|}
\hline NO & INTERVAL & FREKUENSI \\
\hline 1 & $24-28$ & 1 \\
\hline 2 & $29-33$ & 11 \\
\hline 3 & $34-38$ & 14 \\
\hline 4 & $39-43$ & 12 \\
\hline 5 & $44-48$ & 6 \\
\hline 6 & $49-53$ & 1 \\
\hline & JUMLAH & 45 \\
\hline
\end{tabular}

Untuk lebih jelas data diatas dapat digambarkan pada histogram berikut:

\section{CHART TITLE}

$\otimes 124-28 \otimes 229-33 \otimes 334-38 \otimes 439-43 \otimes 544-48 \otimes 649-53$

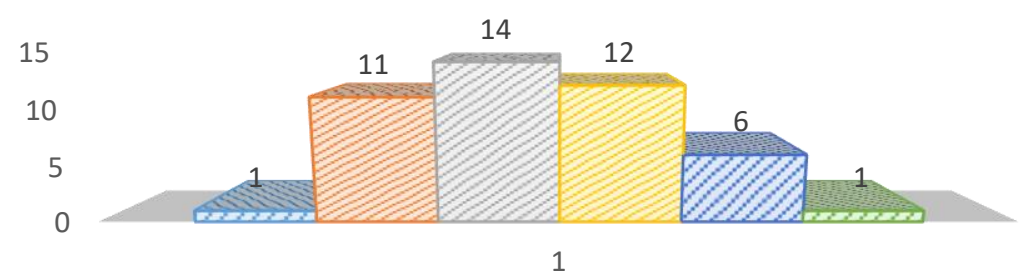

Gambar 1. Histogram Skor Ekonomi Orangtua

Secara berturut-turut gambar diatas menunjukkan responden yang memperoleh skor antara 24-28 sebanyak 1 orang, antara 29-33 sebanyak 
11 orang antara 34-38 sebanyak 14 orang, antar $39-43$ sebanyak 12 orang, antara 44-48 sebanyak 6, dan antara 49-53 sebanyak 1 orang. Untuk mencari gambaran angket ekonomi orangtua dapat diperoleh dengan cara rumus berikut :

$$
\begin{gathered}
\text { ekonomi orangtua }=\frac{\sum \text { skor variabel } x}{\sum_{\text {responden } x \sum \text { item } x \sum \text { bobot tertinggi }}} \times 100 \% \\
=\frac{1711}{45 \times 16 \times 4} \times 100 \%=59,91 \%
\end{gathered}
$$

Dari perhitungan diatas dapat diperoleh skor angket ekonomi orangtua secara kumulatif di Kelas VIII SMP Negeri 9 Padangsidimpuan Kecamatan Hutaimbaru sebesar 59,91\%. Maka, untuk melihat tingkat keberhasilan dalam ekonomi orangtua mengkonsultasikan kepada kriteria penilaian sebagai tabel berikut:

Tabel 5. Ekonomi Orangtua

\begin{tabular}{|c|c|c|}
\hline NO & SKOR & KATEGORI \\
\hline 1 & $0-20 \%$ & Sangat lemah \\
\hline 2 & $21-40 \%$ & Lemah \\
\hline 3 & $41-60 \%$ & Sedang \\
\hline 4 & $61-80 \%$ & Kuat \\
\hline 5 & $81-100 \%$ & Sangat kuat \\
\hline
\end{tabular}

Dari perhitungan diatas dapat dilihat bahwa skor ekonomi orangtua secara kumulatif di Kelas VIII SMP Negeri 9 Padangsidimpuan Kecamatan Hutaimbaru sedang sebesar 59,91\%.

Untuk mengetahui persentase ekonomi orangtua secara keseluruhan dengan rumus:

$$
\propto=\frac{\text { frekuensi data yang bersangkutan }}{\text { jumlah frekuensi }} \times 100 \%
$$

Dari data diatas menunjukkan ekonomi orangtua siswa dengan kategori sangat lemah sebesar 4,44\%, ekonomi orangtua dengan kategori lemah sebesar $31,11 \%$, ekonomi orangtua dengan kategori sedang sebesar $40 \%$, ekonomi orangtua dengan kategori kuat sebesar $15,55 \%$ sedangkan ekonomi orangtua siswa dengan kategori sangat kuat sebesar $8,89 \%$.

Untuk lebih jelas data diatas dapat digambarkan pada histogram berikut: 


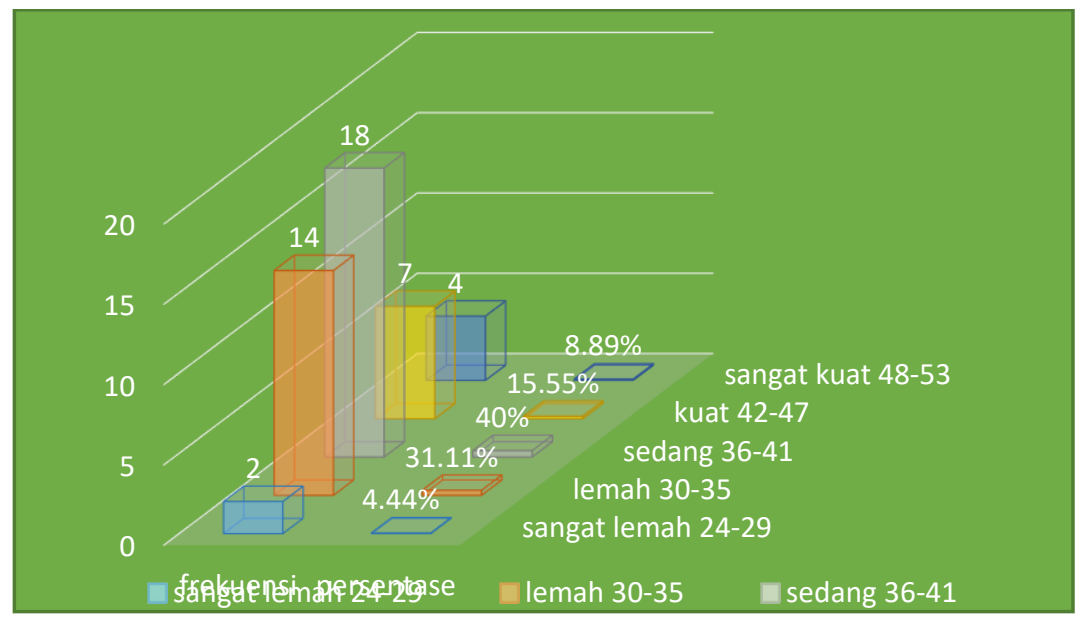

Gambar 2. Histogram Persentase Ekonomi Orangtua

\section{Angket Motivasi Belajar Matematika Siswa}

Tabel 7. Rangkuman Deskripsi Variabel Motivasi Belajar Matematika Siswa

\begin{tabular}{|c|c|c|}
\hline NO & Statistik & Y \\
\hline 1 & Skor terenda & 30 \\
\hline 2 & Skor tertinggi & 53 \\
\hline 3 & Mean & 41,45 \\
\hline 4 & Median & 42,18 \\
\hline 5 & Modus & 44 \\
\hline 6 & Variansi & 6,36 \\
\hline 7 & Standar deviasi & 2,52 \\
\hline
\end{tabular}

Dari tabel diatas skor tertinggi yang dicapai responden mencapai 53, sedangkan skor terendah sebesar 30 dan skor mean (rata-rata) sebesar 41,45. Begitu juga tabel tersebut terlihat skor yang paling sering muncul (modus) sebesar 44 dan nilai tengah (median) sebesar 42,18 sedangkan variansi sebesar 6,36 dan standar desiasi (simpangan baku) sebesar 2,52.

Dengan menentukan jumlah kelas sebanyak 6 dan intervalnya 4 diperoleh sebaran skor motivasi belajar Matematika siswa seperti yang ditunjukkan pada tabel berikut :

Tabel 8. Distribusi Frekuensi Skor Angket Motivasi Belajar Matematika

\begin{tabular}{|c|c|c|}
\hline NO & Interval & Frekuensi \\
\hline 1 & $30-33$ & 2 \\
\hline 2 & $34-37$ & 12 \\
\hline 3 & $38-41$ & 8 \\
\hline 4 & $42-45$ & 11 \\
\hline 5 & $46-49$ & 9 \\
\hline 6 & $50-53$ & 3 \\
\hline & JUMLAH & 45 \\
\hline
\end{tabular}



berikut:

Untuk lebih jelas data diatas dapat digambarkan pada histogram

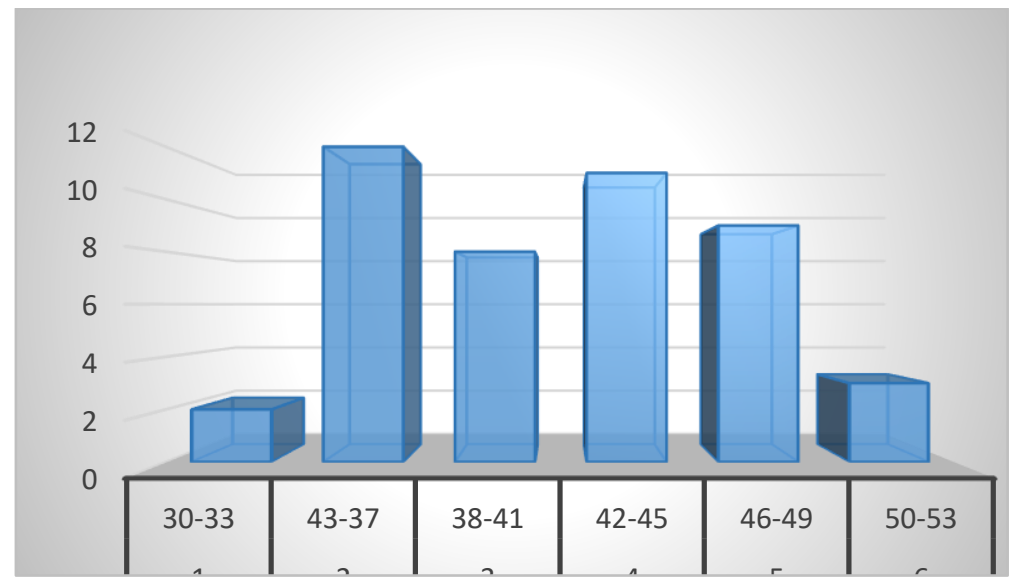

Gambar 3. Histogram Skor Motivasi Belajar Matematika Siswa

Secara berturut-turut gambar diatas menunjukkan responden yang memperoleh skor antara 30-33 sebanyak 2 orang, antara 34-37 sebanyak 12, antara 38-41 sebanyak 8, antara 42-45 sebanyak 9 dan antara 50-53 sebanyak 3 orang. Untuk mencari gambaran angket motivasi belajar Matematika siswa dapat diperoleh dengan cara rumus sebagai berikut :

$$
\begin{aligned}
\text { Motivasi Belajar Matematika }= & \frac{\sum \text { skor vaiabel } x}{\sum \text { responden } x \text { Eitem } x \sum \text { bobot tertinggi }} \times 100 \% \\
& =\frac{1857}{45 \times 16 \times 4} \times 100 \% \\
& =64,4 \%
\end{aligned}
$$

Dari perhitungan di atas dapat diperoleh skor motivasi belajar Matematika secara kumulatif diKelas VIII SMP Negeri 9 Padangsidimpuan sebesar 64,4\%. Maka untuk melihat tingkat keberhasilan dalam motivasi belajar Matematika siswa dengan mengkolsutasikan kepada kriteria penilaian sebagai tabel berikut :

Tabel 9. Kriteria Penilaian Variabel Motivasi

\begin{tabular}{|c|c|c|}
\hline NO & Skor & Kategori \\
\hline 1 & $0-20 \%$ & Sangat rendah \\
\hline 2 & $21-40 \%$ & Rendah \\
\hline 3 & $41-60 \%$ & Sedang \\
\hline 4 & $61-80 \%$ & Kuat \\
\hline 5 & $81-100 \%$ & Sangat kuat \\
\hline
\end{tabular}

Dengan perhitungan diatas dapat dilihat bahwa skor motivasi belajar Matematika siswa Kelas VIIIdi SMP Negeri 9 Padangsidimpuan pada kategori kuat sebesar $64,4 \%$. Untuk mengetahui persentase motivasi belajar siswa secara keseluruhan dengan rumus:

$$
\propto=\frac{\text { frekuensi data yang bersangkutan }}{\text { jumlah frekuensi }} \times 100
$$


Tabel 10. Distribusi Motivasi Belajar Siswa

\begin{tabular}{|c|c|c|}
\hline NO & SKOR & KATEGORI \\
\hline 1 & $3 / 45 \times 100 \%=6,66 \%$ & Sangat rendah \\
\hline 2 & $17 / 45 \times 100 \%=37,77 \% \%$ & Rendah \\
\hline 3 & $12 / 45 \times 100 \%=26,66 \%$ & Sedang \\
\hline 4 & $10 / 45 \times 100 \%=22.22 \%$ & Kuat \\
\hline 5 & $3 / 45 \times 100 \%=6,66 \%$ & Sangat kuat \\
\hline
\end{tabular}

Dari data distribusi diatas menunjukkan motivasi belajar siswa dengan kategori sangat lemah sebesar 6,66\%, motivasi belajar siswa dengan kategori lemah sebesar 37,77, motivasi belajar siswa dengan kategori sedang sebesar 26,66\%, motivasi belajar siswa dengan kategori kuat sebesar $24,44 \%$ sedangkan motivasi belajar siswa dengan ketegori sangat kuat sebesar $4,44 \%$. berikut:

Untuk lebih jelas data diatas dapat digambarkan pada histogram

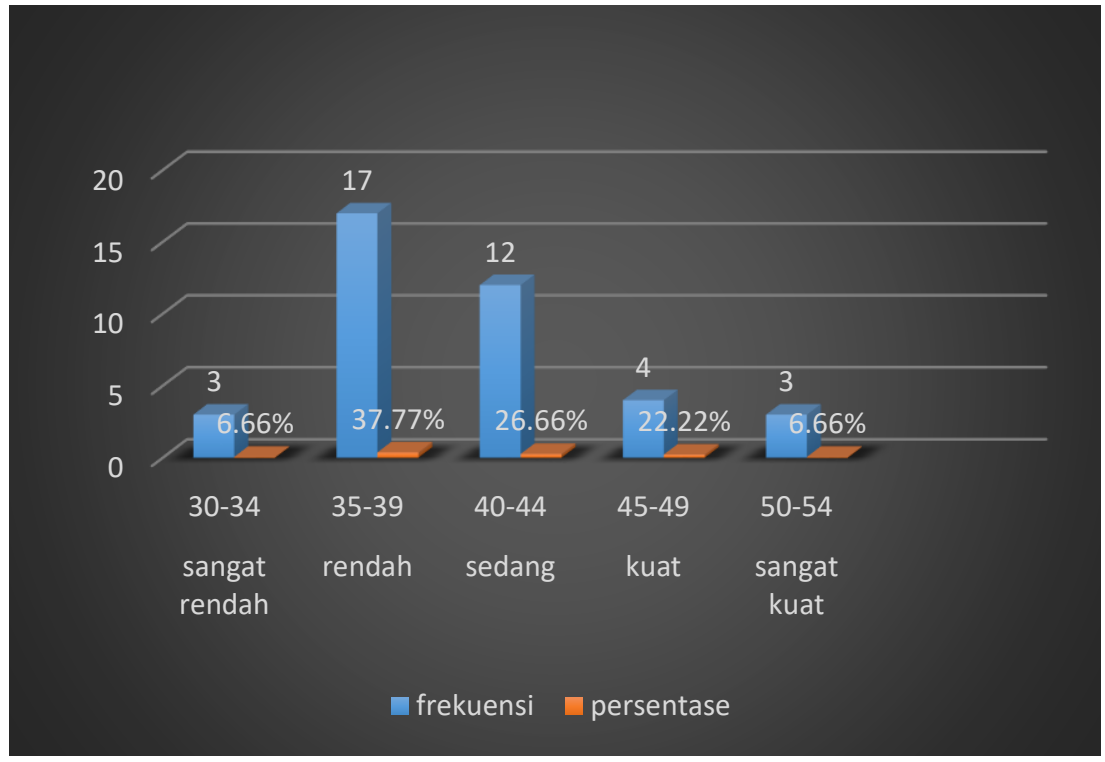

Gambar 4. Histogram Persentase Motivasi Belajar Matematika Siswa

\section{b. Pengujian Hipotesis}

Pengujian hipotesis adanya pengaruh variabel ekonomi orangtua terhadap motivasi belajar Matematika siswa di SMP Negeri 9 Padangsidimpuan dilakukan dengan rumus product moment $\left(\mathrm{r}_{\mathrm{xy}}\right)$ diperoleh nilai 0,172 dengan ketegori sangat rendah dan dibandingkan dengan $r_{\text {tabel }}$ dengan taraf signifikan 5\% Mengingat sampel hanya sampai $45 \mathrm{r}$ tabel yakni, $0,172<0,294$.

Berdasarkan perhitungan koefisien determinan yang bertujuan untuk mengetahui besar kecilnya sumbangan variabel tingkat ekonomi orangtua terhadap motivasi belajar Matematika siswa dalam bentuk persentase, maka diperoleh : $\mathrm{KP}=2,96 \%$. artinya sumbangan antara ekonomi orangtua terhadap motivasi belajar Matematika siswa sebesar 
$2,96 \%$ dan sisanya $97,04 \%$ ditentukan oleh variabel lain yang perlu diteliti lebih lanjut.

Selanjutnya dengan memperoleh persamaan regresi antara variabel $\mathrm{X}$ dan $\mathrm{Y}$ dilihat besar motivasi belajar matematika siswa yaitu dengan persamaan:

$$
\dot{Y}=35.259+0,158 \mathrm{x}
$$

Persamaan regresi sederhana diatas menunjukkan bahwa motivasi belajar matematika siswa Kelas VIII SMP N 9 Padangsidimpuan senilai 35,259 dan arah yang menunjukkan peningkatan atau penurunan sebesar 0,158 dan hasil persamaan regresi menunjukkan dengan taraf signifikan $F_{\text {hitung }}>F_{\text {tabel, dimana }} 1,307>4,075$, artinya tingginya ekonomi orangtua tidak ada pengaruh terhadap motivasi belajar matematika siswa dan begitu sebaliknya rendahnya ekonomi orangtua tidak berpengaruh terhadap motivasi belajar Matematika siswa.

\section{c. Pembahasan Hasil Penelitian}

Berdasarkan penyajian hipotesis diketahui bahwa ekonomi orangtua tidak mempunyai signifikansi terhadap motivasi belajar Matematika siswaKelas VIII SMP Negeri 9 Padangsidimpuan Kecamatan Hutaimbaru. Berdasarkan landasan teoritis yang ada pada Bab II sesuai dengan hasil penelitian yang menjelaskan bahwa adanya pengaruh signifikan antara ekonomi orangtua terhadap motivasi belajar Matematika siswa Kelas VIII SMP Negeri 9 Padangsidimpuan Kecamatan Hutaimbaru. Dengan ekonomi orang tua yang lebih tinggi akan meningkatkan motivasi belajar siswa dalam mengikuti pelajaran matematika tersebut, sebaliknya ekonomi orangtua lemah mengakibatkan rendahnya motivasi belajar Matematika siswa.

Penelitian yang dilakukan dilapangan menunjukkan bahwa hasil penelitian yang dinyatakan baik, dimana ekonomi orangtua tidak ada pengaruh signifikan terhadap motivasi belajar Matematika siswa.

\section{Kesimpulan}

Berdasarkan hasil penelitian dapat disimpulkan bahwa:

1. Hasil dari penelitian ekonomi orangtua secara kumulatif di Kelas VIII SMP Negeri 9 Padangsidimpuan terletak pada kategori sedang yaitu $59,91 \%$.

2. Hasil dari penelitian motivasi belajar secara kumulatif di Kelas VIII SMP Negeri 9 Padangsidimpuan terletak pada kategori kuat yaitu $64,4 \%$.

3. Pengaruh ekonomi orangtua terhadap motivasi belajar Matematika siswa Kelas VIII SMP N 9 Padangsidimpuan disimpulkan bahwa hipotesis yang berbunyi: "Terdapat pengaruh yang signifikan antara ekonomi orangtua terhadap motivasi belajar Matematika siswa Kelas VIII SMP N 9 Padangsidimpuan", ditolak. Hal itu berdasarkan kriteria produc moment diperoleh $\mathrm{r}_{\mathrm{xy}}=0,172$ termasuk kategori yang tidak signifikan, dengan koefisien determinasi $(\mathrm{Kd})=2,96 \%$ artinya sumbangan ekonomi orangtua memberikan konstribusi yang tidak 
signifikan terhadap motivasi belajar Matematika siswa Kelas VIII SMP N 9 Padangsidimpuan sebesar 2,96\% dan sisanya 97,04\% ditentukan oleh faktor lain. Rata-rata ekonomi orangtua dengan kategori sangat rendah sebesar 6,66\%, kategori rendah sebesar $37,77 \%$, kategori sedang sebesar $26,66 \%$, kategori kuat sebesar $22,22 \%$ dan kategori sangat kuat 6,66\%. Dan rata-rata motivasi belajar Matematika siswa dengan kategori sangat rendah sebesar 4,44\%, kategori rendah sebesar $31,11 \%$, kategori sedang sebesar $40 \%$, kategori kuat sebesar 15,55\% dan kategori sangat kuat 8,89\%. Hasil uji regresi yang menunjukkan $\mathrm{F}_{\text {hitung }}<\mathrm{F}_{\text {tabel }}=1,307<4,075$. Taraf signifikan $\mathrm{a}=35.259$ dan $\mathrm{b}=0,158$ dan $\mathrm{n}=45$ uji satu fihak $\mathrm{dk}=\mathrm{n}$ $2=43$, sehingga diperoleh $\mathrm{f}_{\text {tabel }}=4,075$

Maka disimpulkan bahwa tidak ada pengaruh yang signifikan antara ekonomi orangtua terhadap motivasi belajar Matematika siswa Kelas VIII SMP Negeri 9 Padangsidimpuan.

\section{DAFTAR PUSTAKA}

Abdulsyani, Sosiologi Skematika Teori dan Terapan, Jakarta: Bumi Aksara, 2012.

Ahmad Fadhil Lubis, Nur, Etika Bisnis Dalam Islam, Jakarta: Hijri Pustaka Utama, 2002.

Nijar, Ahmad, Metode Penelitian Pendidikan, Bandung:Citapustaka Media, 2015.

Arikunto, Suharsimi, Dasar-dasar Evaluasi Pendidikan, Jakarta: Bumi Aksara, 1993.

Arikunto, Suharsimi,Prosedur Penelitian Suatu Pendekatan Praktik, Jakarta: Rineka Cipta, 2006.

Arikunto, Suharsimi,Managemen Penelitian, Jakarta: Rineka Cipta, 2009.

A.M, Sardiman, Iteraksi dan Motivasi Belajar Mengajar, Jakatarta: Raja Grapindo Persada, 2010.

Anwar, Dessy, Kamus lengkap Bahasa Indonesia, Surabaya: Karya Abdi Tama, 2001.

Ardy Wiyani, Novan, Managemen Pendidikan Karakter Konsep Dan Implikasinya Di Sekolah, Yogyakarta : Pustaka Insan Madani, 2012.

Daradjat, Zakiah, dkk, Ilmu Pendidikan Islam, Jakarta: Bumi Aksara, 2008. 
Ellis Ormrod, Jeanne, Psikologi Pendidikan Membantu Siswa Tumbuh Dan Berkembang, Jakarta : Penerbit Erlangga, 2009.

Hasibuan, Muslim, Dasar-Dasar Kependidikan, Padangsidimpuan : STAIN, 2012

Hamalik, Oemar, Proses Belajar Mengajar, Jakatra: Bumi Akasara, 2010.

Herawni, Linda, "Pengaruh Kreativitas Guru Terhadap Motivasi Belajar PAI di SMP Negeri 1 Desa Sirongit Batu Godang Kecamatan Angkola Sangkunur Kabupaten Tapanuli Selatan", Skripsi, IAIN Padangsidimpuan, 2013.

Masri Kuadrat, Hamzah B. Uno, Mengelola Kecerdasan dalam Pembelajaran Sebuah Konsep Pembelajaran Berbasis Kecerdasan, Jakarta: Bumi Aksara, 2010.

Nengsih, Elda,"Pengaruh Motivasi Dan Pendapatan Orang Tua Terhadap Hasil Belajar Siswa Pada Mata Pelajaran IPS Di SMP Negeri 2 Batang Anai Kecamatan Anai Kabupaten Padang Pariaman”, Jurnal,STKIP PGRI Padang Sumatra Barat, 2013.

Saleh, Abdul Rahman, Psikologi Suatu Pengantar dalam Persfektif Islam Jakarta: Kencana Media Group, 2009.

Slameto, Belajar dan Faktor-faktor yang Mempengaruhinya, Jakarta: Rineka Cipta, 2003.

Suherman, Erman, dkk., Strategi Pembelajaran Matematika Kontemporer, JICA: UPI, 2003.

Sukmadinata, Nana Syaodih, Landasan Psikologi Proses Pendidikan, Jakarta: Rosda Karya, 2004.

Sugiyono, Statistik Untuk Penelitian, Bandung: Alfabeta, 2006.

Sutadipura, Balnadi, Aneka Problematika Keguruan, Bandung: Angkasa, 1983.

Syah, Muhibbin, Psikologi Belajar, Jakarta: Raja Grapindo Persada, 1999.

Prasetyo, Bambang, Metode Penelitian Kuantitatif Teori dan Aplikasi, Jakarta: Raja Grapindo Persada, 2005.

Purwanto, M. Ngalim, psikologi pendidikan, Jakarta: Remaja Rosda Karya Bandung, 1990.

Santrock, Jhon W, Psikologi Pendidikan, Jakarta: Pajar Interpretama Ofset, 2010. 
158 Pengaruh Ekonomi Orangtua..........Nirma Wahyuni, dkk

Yamin, Martinis, Profesionalisasi Guru dan Implementasi Ktsp, Jakatra: Putra Grafika, 2009.

Zuhri, Saifuddin, "Pengaruh Tingkat Ekonomi Orang Tua Terhadap Motivasi Belajar Siswa”, Skripsi, IAIN Walisongo Semarang, 2010. 